\title{
APPLICATION MICROWAVE RADIATION FOR DIRECTIONAL CHANGES OF LAYERED SILICATES PROPERTIES
}

\section{Introduction}

Layered silicates, the majority of which are clay minerals, are associated with numerous mineral deposits and account for about 50\% of all sedimentary rock. Layered silicates can act both as non-metallic minerals - kaolin, bentonite, talc, vermiculite, glauconite, and as components of host rocks for other minerals. The extensive physical and chemical complexity of clays translates to great technological difficulties in the mining and processing stages.

Technological problems are caused by ability of clay to absorb water and to swell, which changes the rheological properties of suspensions, as well as to adhere to valuable minerals [1, 2]. Disintegration of ores containing layered silicates results in formation of anisotropic and highly dispersed mineral particles. Such particles affect the adsorption and rheological properties of water suspensions used at the beneficiation stage [3]. This is due to the peculiarities of the crystal structure of clay minerals. The crystal structure of layered silicates is based on two types of structural elements. Minerals contenting layered silicates consist of tetrahedral $(T)$ and octahedral $(O)$ layers [4]. The layers are arranged in different proportions $(1: 1 ; 2: 1 ; 2: 1: 1)$ and have different interlayer elements, which causes the difference in their physical and chemical properties [5]. There are several classifications of layered silicates and one of them is shown in Fig. 1.

Layered silicates are characterized by their specific interaction with water and aqueous solutions. Water is an

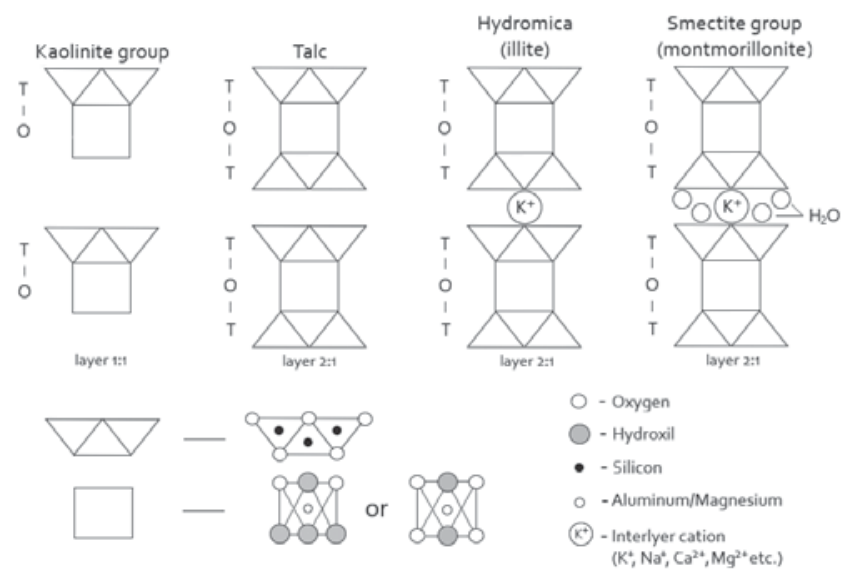

Fig. 1. Diagram of structures of main groups of layered silicates important structural component of clay minerals, and it has essential influence on clay behavior and properties. Clay minerals contain free, physically bound (adsorption, osmotic) and chemically bound (constitutional, crystallization) water.

The presence of water in the structure of layered silicates governs their behavior in suspensions. For some types of clay minerals such as smectite group (montmorillonite), this interaction leads to a change in the interlayer distance between clay particles and to a significant change in the characteristics of the mineral lattice [6]. By the degree of influence on the dynamic viscosity of suspensions, silicate particles arrange the following sequence: talk $<$ kaolinite $<$ illite $<$ montmorillonite, which agrees with the influence of these minerals on technological processes with such suspensions [7].

In this respect, it is reasonable to find a technology that can change the structure of layered silicates at the beginning of a technological cycle so that layered silicates acquire new physical and chemical properties that reduce their impact on beneficiation efficiency. Researchers have thoroughly studied metal-clay interactions through ion exchange [8-10], surface adsorption $[11,12]$ or any other mechanism at low temperatures, low ionic strength and $3<\mathrm{pH}<10$. However, knowledge of the behavior of clay minerals under these conditions lacks a clear answer and understanding for working out a solution to minimize negative impacts on mining and beneficiation processes. In the meanwhile, for this research it is interesting to study the behavior of layered silicates at higher temperatures.

Thermal modification is a promising approach to improving processing of ores containing layered silicates. Thermal modification allows reducing the negative impact of layered silicates on the main technological operations by changing the physical and chemical properties of the clayey component. The main purpose of thermal modification of layered silicates is to change the microstructure of substances. The process 
takes place as sequential removal of free, adsorbed, interlayer and crystallization water [7].

There are four stages of clay heating transformation: lowtemperature and high-temperature dehydration, crystal lattice rearrangement and high-temperature mineral composition changes. When clay minerals are heated up to $500{ }^{\circ} \mathrm{C}$, there are no sharp changes in the mineral phase composition. At this time, absorbed moisture is removed, and the microstructure of the substance is preserved. Phase transformation begins at $550{ }^{\circ} \mathrm{C}$. They are associated with amorphization of clay matter. Clay minerals lose their crystallization and constitution water, and change their structure at $600{ }^{\circ} \mathrm{C}$. Heated at $800{ }^{\circ} \mathrm{C}$ and above, the material is an anisotropic mass with some vitreous areas.

For example, when heated above $550^{\circ} \mathrm{C}(1)$, the structure of kaolinite is irreversibly destroyed by the formation of X-ray amorphous metakaolinite (1) which preserves the structure inherent in kaolinite at a temperature up to $830^{\circ} \mathrm{C}$. At the temperature of $930-1000{ }^{\circ} \mathrm{C}$ crystallization of $\gamma$-alumina (2) and nucleation of mullite $3 \mathrm{Al}_{2} \mathrm{O}_{3} \cdot 2 \mathrm{SiO}_{2}$ starts, and residual silica at $1250{ }^{\circ} \mathrm{C}$ turns into crystobalite (3).

$$
\begin{aligned}
& \mathrm{Al}_{2} \mathrm{O}_{3} \cdot 2 \mathrm{SiO}_{2} \cdot 2 \mathrm{H}_{2} \mathrm{O} \rightarrow \mathrm{Al}_{2} \mathrm{O}_{3} \cdot 2 \mathrm{SiO}_{2}+2 \mathrm{H}_{2} \mathrm{O} ; \\
& \mathrm{Al}_{2} \mathrm{O}_{3} \cdot 2 \mathrm{SiO}_{2} \rightarrow \mathrm{\gamma}-\mathrm{Al}_{2} \mathrm{O}_{3}+2 \mathrm{SiO}_{2} ; \\
& 3 \mathrm{Al}_{2} \mathrm{O}_{3} \cdot 6 \mathrm{SiO}_{2} \rightarrow 3 \mathrm{Al}_{2} \mathrm{O}_{3} \cdot 2 \mathrm{SiO}_{2}+4 \mathrm{SiO}_{2} .
\end{aligned}
$$

Phase changes of other clay minerals, such as hydro mica and montmorillonite, differ from the kaolinite group minerals. Removal of crystallization water with partial restructuring takes place in hydro mica at temperatures above $500{ }^{\circ} \mathrm{C}$, and at $850-1000{ }^{\circ} \mathrm{C}$ hydro mica is completely destroyed. Further heating leads to recrystallization of amorphous products of hydro mica destruction and to formation of spinel $\mathrm{MeAl}_{2} \mathrm{O}_{4}$ $\left(\mathrm{Me}-\mathrm{Mg}^{2+}, \mathrm{Zn}^{2+}, \mathrm{Mn}^{2+}, \mathrm{Fe}^{2+}, \mathrm{Ni}^{2+}, \mathrm{Co}^{2+}\right.$ ) and mullite. Heating of montmorillonite is not accompanied by structural changes, and the lattice of the mineral is preserved in heat treatment, there is only some deformation of it. This behavior of montmorillonite is explained by the low content of crystallization water as compared with kaolin. Crystallization water in montmorillonite is removed at $600-800^{\circ} \mathrm{C}$. Talc undergoes no phase transformations up to $900-1050^{\circ} \mathrm{C}$. At such temperatures, the mineral dehydrates with formation of enstatite and amorphous silica (4). Upon further heating, cristobalite is formed:

$$
\mathrm{Mg}_{3}\left[\mathrm{Si}_{4} \mathrm{O}_{10}\right](\mathrm{OH})_{2} \rightarrow 2 \mathrm{MgSiO}_{3}+\mathrm{SiO}_{2}+\mathrm{H}_{2} \mathrm{O} \text {. }
$$

The type of heating has a significant influence on the change in the structure of layered silicates. There are several methods for thermal modification of the material: convective $[13,14]$ radiation-thermal [15], hydrothermal heating [16], infrared radiation [17], microwave heating [18, 19] and others. Recent studies in this area indicate the expediency of using microwave technology for mica processing - vermiculite and phlogopite [20-22], silvinite ores [23] and layered silicates $[24,25]$.

Microwave heating is carried out by conversion of electromagnetic energy into heat spreading over the entire volume of the material as against traditional heating systems. This mechanism allows removal of moisture from clay materials evenly and deeper at relatively low temperatures and minimized time and energy inputs. In the convection heating method, heat is transferred from the hot part of the boundary layer to the body surface. In this case, the surface temperature of the material to be heated is higher than the material inside. Moisture removal in the convective type of heating occurs gradually as the particle surface temperature increases. A large amount of time and energy should be spent to achieve the desired result.

The feature of layered silicates as an object for microwave heating is the presence of a large number of 'water centers' which are exposed to electromagnetic radiation. The electromagnetic field of microwave influences on layered silicates according to Buger's law and is absorbed mainly by water molecules. Water has a high dielectric loss factor and contributes to the transformation of the large amount of energy into heat versus the dry mass of the substance [26, 27]. Under the influence of the field, the water dipole rotates at a speed of $4.5 \cdot 10^{9} 1 /$ seconds at a frequency of $2.45 \mathrm{GHz}$. This leads to rapid heating of both adsorbed and bound water in layered silicates.

\section{Method and materials}

Common clay minerals were selected to reveal the promising advantages of microwave heating as compared to traditional technologies: montmorillonite, illite, kaolinite, talc, quartz and nepheline. The chemical characteristics of the minerals are presented in Table 1. Ground samples with a particle size of $<0.2 \mathrm{~mm}$ were subjected to heat treatment in various modes. Convective heating was carried out in a muffle electric furnace at $550^{\circ} \mathrm{C}$ with an exposure time of 30 minutes, and microwave heating was executed in microwave Samsung (2.45 GHz; $1 \mathrm{~kW})$ with an exposure time of $1,3,5$, 7, 10, 15 and $20 \mathrm{~min}$. The surface temperature of the heated material was monitored by pyrometer with thermocouple $(0.85<\varepsilon<0.95)$.

Changes in the specific surface of the materials were controlled by adsorption of methylene blue (MB). The chemical analysis of the test raw materials was performed by the $\mathrm{X}$-ray fluorescence (XRF) method using sequential X-ray fluorescence spectrometer (XRF 1800, 40 kV, 90 mA, USA). The structural phase transformation analysis of the studied materials was carried out by means of the X-ray diffraction (XRD) analysis using Bruker D8 focus X-ray diffractometer with Siemens diffractometer 7000 (USA) with $\mathrm{Cu}$-Ka radiation (40 kV, $30 \mathrm{~mA}, \lambda=1.5406 \AA)$. In order to determine the thermal decomposition behavior of the heated material, the thermal gravimetric analysis (TGA) and differential thermal analysis (DTA) used the device THERMOSKAN-2. The material was exposed to the temperature in the range from 25 to $1000{ }^{\circ} \mathrm{C}$ at atmospheric pressure. The heating rate was $10^{\circ} \mathrm{C} / \mathrm{min}$. The particle size distribution of obtained sinters and sludges were assessed in the laser microanalysis using
Table 1. Chemical composition of clayey minerals, mass percentage

\begin{tabular}{|l|c|c|c|c|c|c|c|c|c|c|}
\hline \multicolumn{1}{|c|}{ Mineral } & $\mathrm{SiO}_{2}$ & $\mathrm{Al}_{2} \mathrm{O}_{3}$ & $\mathrm{Fe}_{2} \mathrm{O}_{3}$ & $\mathrm{TiO}_{2}$ & $\mathrm{CaO}$ & $\mathrm{Na}_{2} \mathrm{O}$ & $\mathrm{K}_{2} \mathrm{O}$ & $\mathrm{MgO}$ & $\mathrm{H}_{2} \mathrm{O}$ & LOI \\
\hline Kaolinite & 56.9 & 27.4 & 2.1 & 0.49 & 0.49 & 0.26 & 0.16 & 0.41 & - & 11.2 \\
\hline Montmorillonite & 48.65 & 14.06 & 3.19 & 0.15 & 4.22 & 0.92 & 0.38 & 4.33 & 16.24 & 4.29 \\
\hline Illite & 47.10 & 23.30 & 7.74 & 3.20 & 0.17 & 0.14 & 6.69 & 1.70 & - & 6.64 \\
\hline Talc & 62.7 & 0.13 & 1.4 & - & 0.05 & 0.06 & 0.02 & 30.9 & 4.8 & - \\
\hline
\end{tabular}




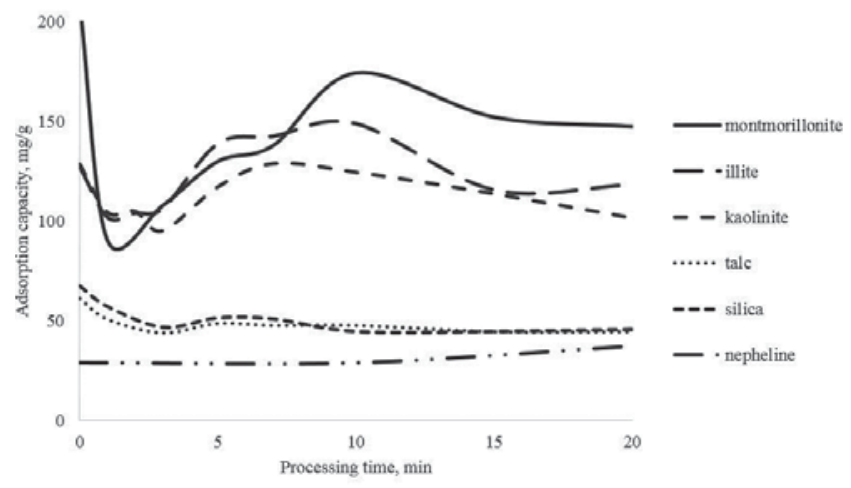

Fig. 2. Change in adsorption capacity of silicates versus microwave processing time

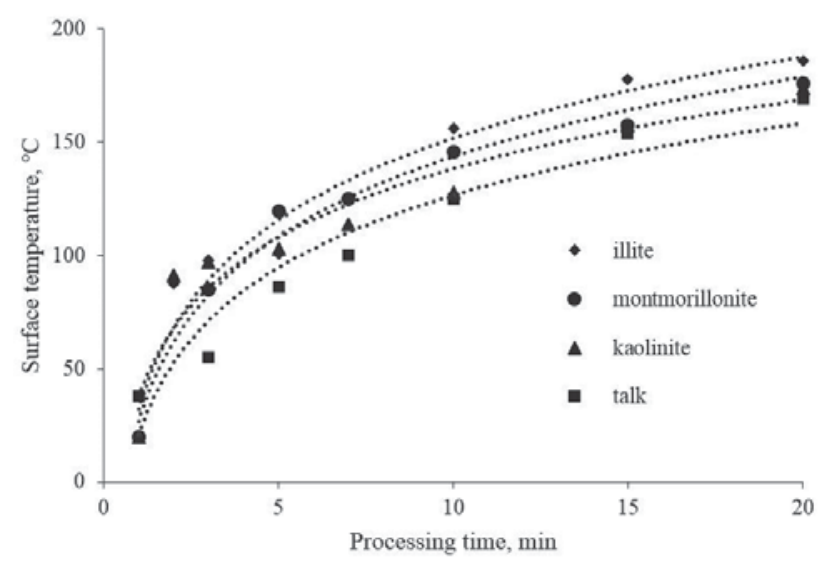

Fig. 3. Surface temperature of layered silicates in microwave heating

the domestic-manufacture analyzer Microsizer 201C and in the range of 0.2 to $300 \mu \mathrm{m}$.

\section{Results and Discussion}

Microwave treatment effect on adsorption properties of layered silicates

The experimental studies on MB adsorption show that montmorillonite, illite and kaolinite have a high adsorption capacity and dielectric permittivity. These minerals are more sensitive to microwave radiation than nepheline aluminosilicates and silicates such as quartz and feldspars. These materials have low dielectric permittivity and do not interact with microwave radiation because they contain no water. Initial nepheline is stable in the temperature range of $200-1200{ }^{\circ} \mathrm{C}$. Quartz changes its structure only at $575{ }^{\circ} \mathrm{C}$ from $\beta$-quartz to a-quartz. These minerals can interact with microwave radiation only in drying when they have free surface water. Therefore, it is only expedient to expose layered silicates to electromagnetic energy in order to change their structure as they contain water in chemical composition.

Talc change insignificantly in microwave processing since it is hydrophobic properties, incapable of swelling and is undehydrated at low temperatures. The change in the structure of talc starts at temperatures above $900^{\circ} \mathrm{C}$ [28].

Dehydration in heating leads to significant damage of the crystal lattice of clay minerals. At the same time, the porosity of
Table 2. Adsorption capacity of materials in different type heating

\begin{tabular}{|l|c|c|}
\hline \multirow{2}{*}{ Layered silicate } & \multicolumn{2}{|c|}{ Adsorption capacity, $\mathrm{mg} / \mathrm{g}$} \\
\cline { 2 - 3 } & 10 & $550-30$ \\
\hline Montmorillonite & 174.11 & 103.04 \\
\hline Illite & 148.84 & 118.31 \\
\hline Kaolinite & 124.36 & 87.06 \\
\hline Talc & 57.76 & 47.27 \\
\hline Quartz & 44.60 & 41.44 \\
\hline Nepheline & 37.07 & 34.72 \\
\hline
\end{tabular}

Comment: 10 - microwave heating $10 \mathrm{~min}$; 550-30 -

convective heating $550^{\circ} \mathrm{C} ; 30 \mathrm{~min}$.

Table 3. Average particle size composition of layered silicates

\begin{tabular}{|c|c|c|c|c|c|}
\hline \multirow{2}{*}{ Size, $\mathrm{mm}$} & \multicolumn{5}{|c|}{ Yield, \% } \\
\cline { 2 - 6 } & 0 & 10 & 20 & 30 & $550-30$ \\
\hline$-0.2+0.125$ & 1.62 & 1.43 & 2.36 & 2.39 & 6.05 \\
\hline$-0.125+0.1$ & 0.85 & 0.74 & 1.25 & 1.26 & 3.06 \\
\hline$-0.1+0.06$ & 1.74 & 2.12 & 3.16 & 2.97 & 5.66 \\
\hline$-0.06+0.04$ & 1.37 & 2,32 & 3.15 & 2.83 & 3.41 \\
\hline$-0.04+0.02$ & 2.38 & 4.50 & 4.73 & 4.28 & 3.82 \\
\hline$-0.02+0.01$ & 4.24 & 4.78 & 4.39 & 4.02 & 2.89 \\
\hline-0.01 & 18.32 & 12.74 & 10.64 & 9.61 & 3.98 \\
\hline
\end{tabular}

Comment: 0 - initial sample; $10,20,30$ - microwave heating

$10,20,30 \mathrm{~min} ; 550-30$ - convective heating $550^{\circ} \mathrm{C} ; 30 \mathrm{~min}$.

the material increases. As a result, a stable mesoporous material with an inherited layered structure is formed. The maximum effect of dehydration of montmorillonite, illite and kaolinite during microwave treatment is achieved in a time interval of 5-10 minutes; the further exposure to radiation reduces the adsorption capacity of minerals (Fig. 2).

Bentonite (montmorillonite) has the highest adsorption capacity among layered silicates. When the temperature of bentonite modification is increased up to $400{ }^{\circ} \mathrm{C}$, a dense crystalline structure is formed, the mechanical strength of the samples grows, and the samples lose the ability to swell $[29,30]$. This mechanism can enable reduction of the impact on the main technological operations during ore beneficiation and on their further metallurgical processing efficiency.

The adsorption capacity of layered silicates in convective processing is lower than in microwave heating (table 2). The value of MB adsorption in layered silicates is $30-70$ units lower than in microwave processing.

Microwave treatment effect on grain size composition of layered silicates

Deformation of the crystal lattice of layered silicates and partial coarsening occurs with an increasing time of microwave radiation. The size fraction analysis of heat-treated kaolin shows that the fine size $(-0.01)$ decreases 2 times from 18.32 to $9.61 \%$ during microwave processing and to $3.98 \%$ during convective heating due to the formation of loose-packed aggregates. Such aggregates are formed as a result of reduction in the interplayed distance during removal 


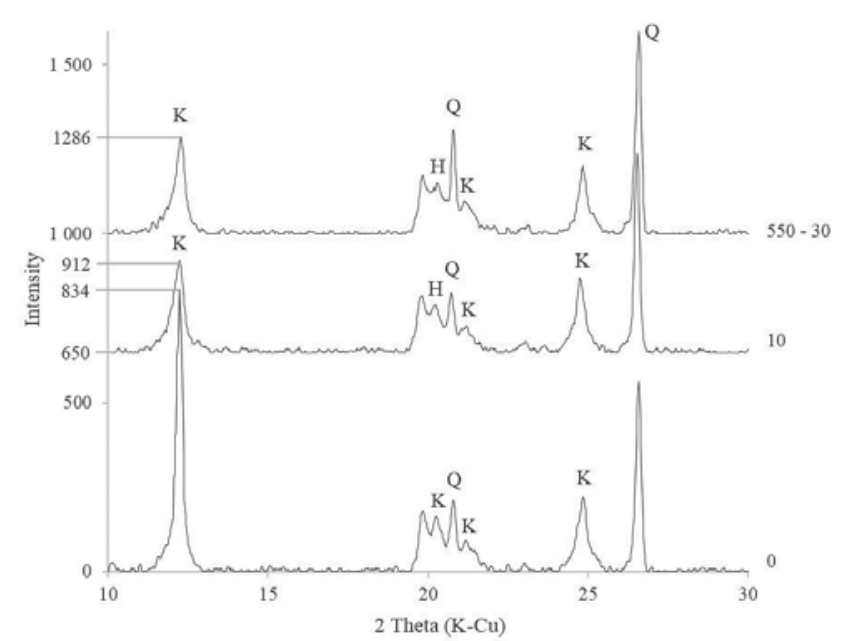

Fig. 4. X-ray phase analysis of kaolin samples:

0 - initial sample; 10 - MW 10 min; 550-30 - convective heating $\left(550^{\circ} \mathrm{C} ; 30 \mathrm{~min}\right)$;

$\mathrm{K}$ - kaolinite; $\mathrm{H}$ - dehydrated halloysite; $\mathrm{Q}$ - quartz

of crystallization water. The data on the average particle size composition of layered silicates after thermal modification are compiled in Table 3.

Surface temperature change

In microwave heating, there can be internal and external temperatures. The external temperature is a surface temperature. The surface temperature is the average temperature of particles, internal water and air. Measuring the true temperature inside a material is a technically complex process [31]. There is no consensus on how to measure the internal temperature. Thus, the material temperature data are not an absolute value, and the true internal temperature may have higher values.

The surface temperature data are shown in Fig. 3. The temperature curve is a logarithmic dependence which holds true for all test layered silicates. It should be noted that a jump in the surface temperature is observed in the period of free and adsorbed water removal (1-5 min). After $10 \mathrm{~min}$, the temperature changes rate decreases, the material keeps heating up owing to interaction of electromagnetic radiation with chemically bound water although less intensively.

In convective heating, the surface temperature of heated material in the found mode is equal to the temperature inside the material $\left(550^{\circ} \mathrm{C}\right)$. At the same time, in microwave heating of layered silicates, the material surface has lower temperature as compared with convective heating. During the experimental studies, the maximum surface temperature of microwave processing of samples never exceeded $200^{\circ} \mathrm{C}$.

Microwave treatment effect on phase transformation mechanism

Among layered silicates, kaolinite had low-temperature phase transformations after microwave heating. These transformations are important for ore beneficiation and metallurgical processing, for example, in alumina production. Kaolinite group minerals are also associated with numerous mineral deposits. Therefore, this section discusses the impact of microwave heating on kaolinite phase composition.

A large and extensive set of clay characterization techniques is available. The direct evidence of the presence of a certain clay species can only be gathered using probes which measure structural aspects, e.g. XRD, IR or XAS. However, only one type of analysis is not enough and it is necessary to use a secondary tool, for example, DTA and TGA measurement or SSA-EGME.

After thermal treatment, kaolinite in kaolin is first transformed to metakaolin which is usually undetectable by XRD [32]. The XRD analysis (Fig. 4) shows that the peak height of kaolinite lowers after thermal treatment (from 834 to 262), and a new phase - dehydrated halloysite - is formed. Kaolinite and halloysite have a similar structure, but the latter has some interlayer water $(d=9.5 \div 10.2 \AA)$. In dehydration, the inter-plane distance of halloysite approaches the value of kaolinite $(d=7.2 \AA)$. It should be noted that the height of the first peak, which is an indication of kaolinite after microwave treatment (262), is 24 units below the peak in convection treatment (286). The formation of dehydrated halloysite and the decreased height of the kaolinite peak in the diagram are reflective of the positive effect of microwave radiation on layered silicates.

The differential thermal analysis (Fig. 5) shows that an initial sample (a) has an endothermic effect in the temperature range of $100-200{ }^{\circ} \mathrm{C}$, the peak of which falls at $140{ }^{\circ} \mathrm{C}$. This effect is associated with the removal of physically bound water from the channels and pores of the initial material at the maintained microstructure. Heat treatment leads to a reduction in the height of the endothermic peak since free water is largely removed from kaolin at low temperatures. The next endothermic effect of the initial sample is pronounced in the temperature range of $500-600^{\circ} \mathrm{C}$. This is a key effect as it points at the change in the material microstructure and at the formation of metakaolinite. Heat treatment of the samples also decreases
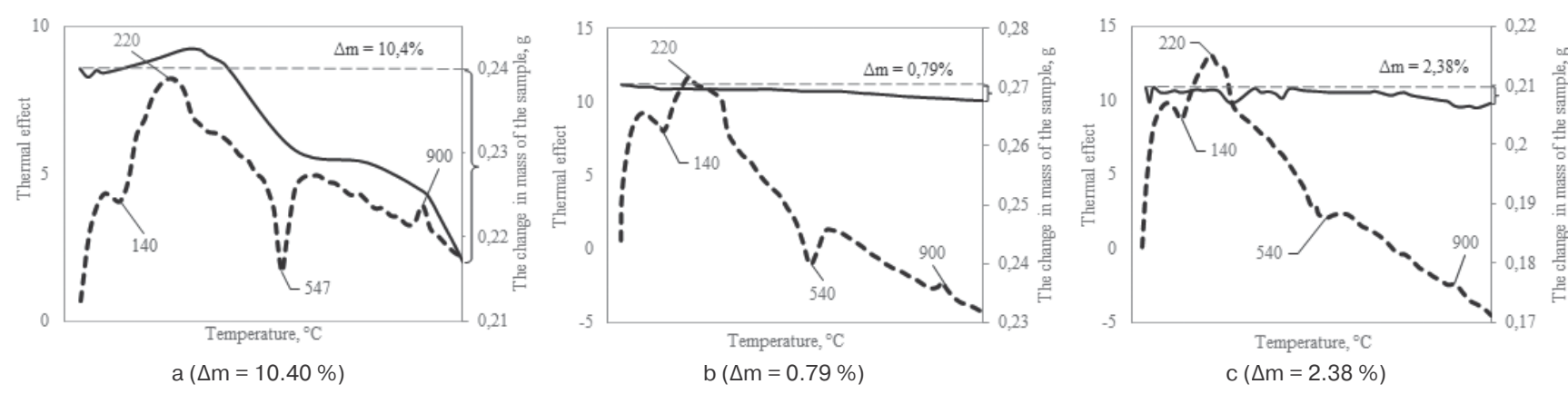

Fig. 5. Differential thermal analysis of kaolin samples:

(a) initial sample; (b) microwave processing $10 \mathrm{~min}$; (c) convective heating $550^{\circ} \mathrm{C} 30 \mathrm{~min}$ 
Table 4. Concentrate production data

\begin{tabular}{|l|c|c|c|c|}
\hline \multirow{2}{*}{ Method } & \multicolumn{2}{c|}{ Content, \% } & \multicolumn{2}{c|}{ Extraction, \% } \\
\cline { 2 - 5 } & $\mathrm{Al}_{2} \mathrm{O}_{3}$ & $\mathrm{Fe}_{2} \mathrm{O}_{3}$ & $\mathrm{Al}_{2} \mathrm{O}_{3}$ & $\mathrm{Fe}_{2} \mathrm{O}_{3}$ \\
\hline Hydrothermal $[4]\left(200^{\circ} \mathrm{C} ; 1.5 \mathrm{MPa}\right)$ & 30.1 & 1.29 & 91.1 & 50.9 \\
\hline Microwave $(2.45 \mathrm{GHz} ; 1 \mathrm{~kW} ; 10 \mathrm{~min})$ & 30.3 & 1.77 & 78.6 & 55.4 \\
\hline Convective $\left(550^{\circ} \mathrm{C} ; 30 \mathrm{~min}\right)$ & 33.5 & 2.10 & 88.4 & 52.0 \\
\hline
\end{tabular}

the height of the endothermic peak. It should be noted that removal of water during microwave treatment (b) occurs uniformly throughout the volume as opposed to convective heating (c). This effect is traceable by the magnitude of the endothermic peaks, which indicate the removal of adsorbed and constitutional water, and by the curve of the change in the mass of kaolin samples. The results are proved by the data on the surface temperature of the material after microwave treatment (Fig. 3).

Application of microwave heating in processing of layered silicates

Significant changes are observed in the sample after thermal modification for 10 minutes. The magnitude of the exothermic and endothermic effects indicates the beginning of microstructure change in the sample. According to the mass change value, after 10 minutes of microwave treatment, there is a potential opportunity to obtain a dehydrated material with the changed structure and process properties. This makes it possible to use microwave treatment of ores containing layered silicates in their processing.

We made an attempt to develop a technological flow chart of kaolin beneficiation based on the theoretical studies of microwave modification. Table $\mathbf{4}$ gives the production data of concentrates obtained during processing with various preliminary thermal modification (microwave, hydrothermal, convection). The previous research findings can be found in [4]. The processing technology for kaolin includes some basic stages as follows. Initial kaolin ore goes to disintegration in toothed roller crusher and, then, the crushed product is sent to microwave treatment. After that the product is screened, and the undersize $(-0.2 \mathrm{~mm})$ is an end product (concentrate) ready for further metallurgical processing. Microwave modification shows the same values as the other types of heating. Technologically the concentrates are suitable for further processing.

\section{Conclusions}

The extensive physical and chemical complexity of clay minerals translates to great technological difficulties in mining and processing: water absorption, suspension rheology, suspension settling, clay-mineral adhesion.

Microwave heating for thermal modification of layered silicates is effective only in the temperature range of $100-400^{\circ} \mathrm{C}$ as the component which interacts with electromagnetic radiation vanishes at higher temperatures.

Electromagnetic radiation interacts with water contained in layered silicates during microwave heating. This is the basis for heating the material.

Microwave heating changes adsorption capacity and surface properties of layered silicates, promotes formation of loosely packed aggregate, removes water and changes structure of the sample.
The maximum dehydration effect of layered silicates in microwave treatment is achieved in the time period of $10 \mathrm{~min}$ at $1 \mathrm{~kW}$ and $2.45 \mathrm{GHz}$. Kaolinite acquires a structure comparable to a material after convection heating and a high specific surface area as opposed to heating in a muffle furnace.

Application of microwave heating allows modification of the structure and technological properties of ores containing layered silicates at lower material temperatures than in convective heating. This may become the basis for reducing energy consumption in thermal modification of ores.

The study shows that microwave heating is a promising tool for beneficiation and metallurgical processes. Therefore it is required to analyze the effect exerted by microwave heating on activation of clay ores for processing with acidic methods to produce alumina.

The attempt has been made to develop the process flow chart for kaolin beneficiation for alumina production based on the theoretical studies of microwave modification. The extraction of alumina under microwave radiation has made $79 \%$, which is comparable to other types of heating (hydrothermal $91 \%$, convective $-88 \%$ ).

\section{Acknowledgement}

The study was supported by the Russian Science Foundation, Project No. 19-79-10114.

References

1. Kara-sal B. K., Sapelkina T. V. Improving the adsorption properties of clay rocks of Tuva, depending on the activation methods. Aktualnye problemy sovremennoi nauki. 2012. No. 5. pp. 158-162.

2. Peng Zh. Effects of surface roughness and film thickness on the adhesion of a bio-inspired nanofilm. Bio-inspired Studies on Adhesion of a Thin Film on a Rigid Substrate. 2013. pp. 55-70.

3. Cruz N., Forster J., Bobicki Erin R. Slurry Rheology in Mineral Processing Unit Operations: A Critical Review. The Canadian Journal of Chemical Engineering. 2019. Vol. 97 (7). DOI: 10.1002/cjce.23476

4. Osipov V. I., Sokolov V. N. Clays and their properties. Composition, structure and formation of properties. Moscow, 2013.

5. Ndlovu B., Forbes E., Farrokhpay S., Becker M., Bradshaw D. et al. A preliminary rheological classification of phyllosilicate group minerals. Minerals Engineering. 2014. Vol. 55. pp. 190-200.

6. Fedorin R. P., Khramchenkov M. G. Clay swelling and clay filtration. Uchenye Zapiski Kazanskogo gosudarstvennogo universiteta. 2010. Vol. 152(1). pp. 235-243.

7. Gerasimov A. M., Arsentyev V. A. Layered silicates and their influence on mineral processing. Obogashchenie Rud. 2018. No. 5. pp. 22-28. DOI: 10.17580/or.2018.05.04

8. Eloussaief M., Jarraya I., Benzina M. Adsorption of copper ions on two clays from Tunisia: $\mathrm{pH}$ and temperature effects. Applied Clay Science. 2009. Vol. 46. pp. 409-413.

9. Xu D., Tan X. L., Chen C. L., Wang, X. K. Adsorption of Pb (II) from aqueous solution to $\mathrm{MX}-80$ bentonite: Effect of $\mathrm{pH}$, ionic strength, foreign ions and temperature. Applied Clay Science. 2008. Vol. 41. pp. 37-46.

10. Yu S. M., Ren A. P., Chen C. L., Chen Y. X., Wang X. Effect of $\mathrm{pH}$, ionic strength and fulvic acid on the sorption and desorp- 
tion of cobalt to bentonite. Applied Radiation and Isotopes. 2006. Vol. 64. pp. 455-461.

11. Churakov S. V., Dahn, R. Zinc adsorption on clays inferred from atomistic simulations and EXAFS spectroscopy. Environmental Science \& Technology. 2012. Vol. 46, No. 11. pp. 5713-5719.

12. Macht F., Eusterhues K., Pronk G. J., Totsche, K. U. Specific surface area of clay minerals: Comparison between atomic force microscopy measurements and bulk-gas $(\mathrm{N}-2)$ and -liquid (EGME) adsorption methods. Applied Clay Science. 2011. Vol. 53, No. 1. pp. 20-26.

13. Al-Ajeel A. A., Al-Sindy S. I. Alumina recovery from Iraqi kaolinitic clay by hydrochloric acid route. Iraqi Bulletin of Geology and Mining. 2006. Vol. 2 No. 1. pp. 67-76.

14. Al-Zahrani A. A., Abdul-Majid M. H., Extraction of alumina from local clays by hydrochloric acid process. Journal of King $A b$ dulaziz University: Engineering Sciences. 2009. Vol. 20. No. 2. pp. 29-41.

15. Kotova O. B., Razmyslov I. N., Rostovtsev V. I., Silaev V. I. Radiation-thermal modification of ferruginous bauxite in the processes of their processing. Obogashchenie Rud. 2016. No. 4. pp. 16-23. DOI: 10.17580/or.2016.04.03

16. Arsentyev V. A., Gerasimov A. M., Mezenin A. O. Kaolines beneficiation technology study with application of hydrothermal modification. Obogashchenie Rud. 2017. No. 2. pp. 3-9. DOI.10.17580/or.2017.02.01

17. Rakhimov R. K., Rashidov K. K., Yermakov V. P., Rashidov J. K., Allabergenov R. J. Recource saving and energy efficient technology of the production alumina from secondary kaolin with Angren deposit. Computational nanotechnology. 2016. No. 1 pp. 45-51.

18. Prokopenko A. Microwave heating for emolliating fracture of rocks. Advances in Induction and Microwave Heating of Mineral and Organic Materials. Ed. by S. Grundas. 2011. 752 p.

19. Singh S., Gupta D., Jain V., Sharma A.K. Microwave processing of materials and applications in manufacturing industries; A review. Materials and Manufacturing Processes. 2015. Vol. 30. pp. 1-29.

20. Folorunso O., Dodds C., Dimitrakis G., Kingman S. Continuous energy efficient exfoliation of vermiculite through microwave heating. International Journal of Mineral Processing. 2012. Vol. 114-117. pp. 69-79.

21. Obut A., Girgin J., Yorukoglu A. Microwave exfoliation of vermiculite and phlogopite. Clays and Clay Minerals. 2003. Vol. 51, No. 4. pp. 452-456.
22. Udoudo O., Folorunso O., Dodds C., Kimgman S., Ure A. Understanding the performance of a pilot vermiculite exfoliation system through process mineralogy. Minerals Engineering. 2015. Vol. 82, pp. 84-91.

23. Arsentyev V. A., Gerasimov A. M., Kotova E. L. Thermochemical modification of sylvinite ore using microwave heating. Obogashchenie Rud. 2017. No. 6. pp. 3-8. DOI:10.17580/ or.2017.06.01

24. Al-Bakain R. Z., Al-Degs Y. S., Issa A. A., Jawad A., AbuSafieh K. A., Al-Ghouti M. A. Activation of kaolin with minimum solvent consumption by microwave heating. Clay Minerals. 2014. Vol. 49. pp. 667-681.

25. Zhongzhurist I. A. Microwave processing of silicate molding mixtures with alumina additives. Liteynoe proizvodstvo. 2015 No. 10. pp. 18-22.

26. Binner E., Lester E., Kingman S., Dodds C., Robinson J. et al. A Review of Microwave Coal Processing. Journal of Microwave Power and Electromagnetic Energy. 2014. Vol. 48, No. 1. pp. 35-60.

27. Leluk K., Orzechowski K., Jerie K., Baranowski A., SŁonka T. et al. Dielectric permittivity of kaolinite heated to high temperatures. Journal of Physics and Chemistry of Solids. 2010. Vol. 71, No. 5. pp. 827-831.

28. Yakovleva A. A., Chyong S. N. The study of the absorption capacity of talc. Vestnik Irkutskogo gosudarstvennogo tekhnicheskogo universiteta. 2010. No. 5. pp. 224-229.

29. Belichinskaya L. I., Khodosova N. A., Novikova L. A. The influence of various mechanisms of heating layered aluminosilicate on sorption processes. Sorbtsionnye i khromatograficheskie processy. 2017. Vol. 17, No. 5. pp. 781-791.

30. Binnatova L. A., Shiralieva E. M., Yagubov A. I., Muradova N. M., Nuriev A. N. Heat treatment of bentonite and adsorption of methylene blue. Condensirovannye sredy $i$ Mezhfaznye Granitsy. 2007. Vol. 9, No. 2. pp. 99-101.

31. Yoshikawa N., Tokuyama Y. Numerical Simulation of Temperature Distribution in Multi-Phase Materials as a Result of Selective Heating by Microwave Energy. The Journal of microwave power and electromagnetic energy. 2009. Vol. 43, No. 1. pp. 27-33.

32. Qiao X. C., Si P., Yu J.G. A systematic investigation into the extraction of aluminum from coal spoil through kaolinite. Environmental Science and Technology. 2008. Vol. 42, No. 22. pp. 8541-8546.

33. Ivanova V. P., Kasatov B. K., Krasavina T. N. et al. Thermal analysis of minerals and rocks. Leningrad : Nedra, 1974. 399 p. EW 